\title{
From Entitlement to Contribution
}

\section{Robert Caldwell}

\author{
KEYWORDS: Entrepreneurship, Management, \\ Leadership, Family Business.
}

When a father, absent during the day, returns home at six, his children receive only his temperament, not his teaching. -- Robert Bly

A client told me once that all a family member needed to come into his family business was to pass "the mirror test." If he or she could fog a mirror with breath, that was enough to come to work in the business. The third generation was working to change that mindset as they moved into leadership roles. The old policy has created hard feelings and difficult situations. When the significant jobs are occupied by relatives, change comes slowly and often with pain.

The problem with lower barriers of entry for family members is that you get lower quality employees. In your business you want to continually develop positive contributors and cull the non-performers. If you don't, you quickly lose your competitive edge. Many otherwise feasible businesses fail at times of succession for lack of competent next generation leaders.

My old mentor, Arno, used to call this stepping up and developing myself to the next level as "getting off the balcony and onto the trading floor." For those willing to do more than be consumers of others' work and to contribute to the well-being of the enterprise, welcome. For those who are not, adios.

There comes a time when we are all asked to move from the balcony to the trading floor, to take up our tasks and do them to the best of our abilities. We are asked to move from entitlement to contribution. A question I generally ask of my senior generation clients is, "If your son/daughter/niece/nephew were not related to you, would they still be working here?" While this is a true reality test for many a distraught parent, oftentimes the answer is, "No, if he weren't my son, he'd have been gone a long time ago."

\section{A Breeding Ground for Resentment}

Business leaders who tolerate entitled relatives in key positions are delivering the underlying message that we'll tolerate poor performance or behavior, but we'll harbor a grudge that will damage the relationship even further. This tension becomes a breeding ground for resentment that spreads to non-family employees who begrudge the nepotism.

This tension can split the family in other ways. In a recent client case the mother thought her son should inherit her family's $50 \%$ interest in the business soon, while the father said the exact words above; he'd have fired their son long ago! They were at an impasse when I was called in to work with them.

While it's easy to say we develop top performers and cull those who are not, if they're relatives, emotional ties make it difficult to demote them or let them go. Often a closely held company will have one or two relatives who would be better off elsewhere, but no one has found a way or the nerve to make it happen.

How then do you handle such a situation?

- Remove yourself from the middle to the degree possible. Turn your child/relative over to someone else in the company for tutoring, mentoring, training, discipline; whatever the need. Find a coach or trusted advisor who can serve the function if there's no one internally. Next generation employees deserve the opportunity to develop. Other, perhaps older relatives may deserve another chance, but they also require leadership and accountability.

- Step two, if necessary, is to prepare to make the tough decision to let a relative go. You know or can imagine how difficult it can be to make these calls, but it's a crucial part of family business leadership. Don't be afraid to seek advice about how to handle it. You're not the first to be in this quandary; many others have done it and have been glad they did.

- Finally, next generation employees need to be prepared, allowed to make decisions and some mistakes. Be prepared to stretch them. Give them meaningful things to do from which they
Copyright $\odot$ The Authors. Entrepreneur \& Innovation Exchange is published at EIX.org. This is an open access article under the terms of the Creative Commons Attribution-NoDerivs License, which permits use and distribution in any medium, provided the original work is properly cited and no modifications or adaptations are made. View EIX.org Authorship Terms at https://eix.org/terms
FamilyBusiness 
can learn. This is how they prepare to contribute to the business. Low performers will remain a source of irritation and mutual resentment until a resolution is reached.

The wise poet Robert Bly says that we tend to get either our parents' temperament or their teaching. Even though it's tough when you're frustrated or angry, if your younger relatives are going to stay in the business working with you, they need your teaching and not just your temperament.

\section{More Articles on Managing}

\section{Relatives}

When Entrepreneurs Raise Entrepreneurs (https://familybusiness.org/content/When-entrepreneursraise-entrepreneurs)

"There's No Birthright" and Other Tips for Raising Entrepreneurial Leaders (https://familybusiness.org/content/Theres-no-birthrightand-other-tips-for-raising)

How Family Business Leaders Can Encourage Both Devotion and Performance (https://familybusiness.org/content/How-family-businessleaders-can-encourage-both-d)

The Family Way: How Entrepreneurial Values Help Businesses Thrive Over Generations (https://familybusiness.org/content/the-family-way-howentrepreneurial-values-help-b)

Why Family Firms are like Jenga (https://familybusiness.org/content/why-family-firms-arelike-jenga)

The Fredo Factor: How Deadbeats and Troublemakers Hurt Family Businesses (https://familybusiness.org/content/the-fredo-factor-howdeadbeats-and-troublemakers) 